\title{
Conservation Easements: Options for Preserving Current Land Uses 1
}

\section{Chris Demers and Douglas R. Carter ${ }^{2}$}

Conservation easements are cost-effective means for goverment agencies or non-government conservation organizations to protect land. Instead of purchasing land outright, these agreements allow organizations to purchase the development rights of a property, thereby protecting the target resources and saving money. Conservation easements may be a viable option for landowners wanting to prevent future residential and commercial development of their land, and those who want to reduce their heirs' inheritance tax liability. They often work best for landowners who have a strong connection to their land and want to ensure its protection for many generations. Landowners are encouraged to enter such agreements carefully because they require several rights to be conveyed to the easement grantee and the duration of these agreements is perpetual. This publication will describe conservation easements, what is involved in establishing one, some of the tax implications of such agreements, the government and non-government organizations that commonly participate in conservation easements, and important considerations for landowners before entering into such an agreement.

\section{What Is a Conservation Easement?}

A conservation easement is a voluntary, legally binding agreement between a landowner and a government agency or non-government conservation organization that keeps land in natural habitat, agricultural and/or open space uses. The agreement is customized to meet the landowner's and conservation entity's objectives and, in most cases, is perpetual.

In essence, the landowner sells or donates certain rights to use the land, which typically include the right to develop all or part of his/her land for non-agricultural or non-natural habitat, or non-open space uses to a conservation organization. Current uses, including residential and recreational uses, agriculture, forestry, and ranching can continue under certain, legally-binding stipulations. The easement will protect qualities of the property such as wildlife habitat, open space, forest management or aesthetics. Public access to the property is not a requirement to participate in a conservation easement, but the easement grantee will reserve the right to enter the property to monitor compliance with the agreement.

1. This document is SS-FOR-21, one of a Forest Stewardship Program series of the School of Forest Resources and Conservation, Florida Cooperative Extension Service, Institute of Food and Agricultural Sciences, University of Florida. First published: January 2004. Funding for the production of this publication is provided by the USDA Forest Service through the Florida Department of Agriculture and Consumer Services Division of Forestry. Please visit the EDIS Web site at http://edis.ifas.ufl.edu.

2. Chris Demers is Forest Stewardship Coordinator and Douglas R. Carter, Associate Professor, School of Forest Resources and Conservation, Cooperative Extension Service, Institute of Food and Agricultural Sciences, University of Florida, Gainesville, FL 32611.

The Institute of Food and Agricultural Sciences (IFAS) is an Equal Employment Opportunity - Affirmative Action Employer authorized to provide research, educational information and other services only to individuals and institutions that function without regard to race, creed, color, religion, age, disability, sex, sexual orientation, marital status, national origin, political opinions or affiliations. For information on obtaining other extension publications, contact your county Cooperative Extension Service office. Florida Cooperative Extension Service / Institute of Food and Agricultural Sciences / University of Florida / Larry R. Arrington, Interim Dean 


\section{How the Agreement Works}

Generally, conservation easements are donations rewarded by certain tax benefits to the landowner. In Florida, perpetual conservation easements may be either donated or purchased through less-than-fee payments to the landowner. If the easement is purchased, the payment is negotiated between the landowner and conservation entity and may be as much as an amount equal to the difference between the fair market value of the land without the easement and fair market value of the land with the easement.

For example, Joe and Jolene Landowner have property in Alachua County with planted pines, old pastures and mixed hardwoods. The family is interested in growing and harvesting pines, hunting, bird watching, and some future forestry and wildlife habitat improvements on the property. They want the property protected from residential and commercial development and they plan on passing the property on to their children with a decreased tax burden, so they decide to convey a conservation easement. Being close to a growing urban area, the land has a fair market value of $\$ 3,500$ per acre. The property appraiser determines that the overall current value of the property with a conservation easement is $\$ 1,500$ per acre since no major residential or commercial development can occur on the property at any time in the future. Therefore, the landowner could receive as much as $\$ 2,000$ per acre for the easement, and since the placing of the easement generally reduces the value of the property, the heirs' estate tax liability should also be reduced.

\section{Legal Stipulations}

A conservation easement agreement will require the landowner to convey certain rights to the agency or organization that purchases the easement, and specifies uses prohibited on the property that will allow the easement to accomplish its intended conservation purposes. The grantor's reserved rights are also specified in the agreement. Examples of these stipulations, from a Florida Division of State Lands Deed of Conservation Easement, are outlined below.

\section{Rights Granted to the Grantee}

Some or all of these rights may be conveyed to the grantee by a conservation easement:

1. the right to preserve and protect the conservation values of the property;

2. the right to enter the property at reasonable times in order to monitor compliance with the agreement;

3. the right to prevent any activity on or use of the property that is not consistent with the purpose or provisions of the easement and to require the restoration of areas or features of the property that may be damaged by inconsistent activity or use at the grantor's cost;

4. the right of first refusal to purchase the property in fee if the grantor proposes to sell the property to a third party other than a lineal descendant, and the right to purchase the property from the estate or trust of the grantor (void if easement is a charitable donation for no consideration);

5. the right to be indemnified by grantor for any and all liability, loss, damage, expense, judgment or claim arising out of any negligence, willful action or activity resulting from the grantor's use of the property or use of the property by the grantor's agents, guests, lessees, or invitees.

\section{Prohibited Uses}

Activities on or use of the property not consistent with the purpose of the easement are prohibited under a conservation easement agreement. The following are some examples of prohibited activities specified in a conservation easement agreement:

1. no soil, trash, liquid or solid waste, hazardous materials, or pollutants defined by federal or Florida law shall be dumped or placed on the property;

2. activities or uses that will be detrimental to drainage, flood control, water conservation, erosion control, soil conservation, or fish and wildlife habitat conservation; 
3. activities or uses detrimental to the structural integrity or physical appearance of any portions of the property having historical, archaeological or cultural significance;

4. planting of invasive exotic plants listed by the Florida Exotic Pest Plant Council, and the grantor shall control invasive exotic plants on the property;

5. commercial or industrial activity, or ingress or egress across or upon the property in conjunction with any commercial or industrial activity, except as may be required for the exercise of the grantor's reserved rights;

6. new construction or placing of buildings, mobile homes, signs, billboards or other structures on the property;

7. creation of new roads or jeep trails;

8. no more intense agricultural use of the property than currently exists on the property, if any, and no conversion of non-agricultural areas to agricultural use;

9. activities that adversely impact threatened or endangered species;

10. any subdivision of the land.

\section{Grantor's Reserved Rights}

Some or all of these rights are reserved to the grantor and the grantor's representatives, heirs, successors, and assigns:

1. the right to observe, maintain, photograph, fish, hunt, introduce and stock native fish or wildlife on the property, to use the property for non-commercial hiking, camping, and horseback riding, in compliance with federal, state and local laws concerning such activities;

2. the right to conduct prescribed burning on the property, provided that the grantor obtain and comply with the appropriate authorization from the regulatory agency having jurisdiction over this activity;
3. the right to harvest timber or other forest products in accordance with an approved forest management plan;

4. the right to mortgage the property;

5. the right to contest tax appraisals, assessments, taxes, and other charges on the property;

6. the right to use, maintain, repair, and reconstruct, but not relocate or enlarge, all existing structures, fences, roads, ponds, drainage ditches and other facilities on the property.

\section{Tax Implications of Conservation Easements}

Many factors influence the decision of landowners to consider encumbering development and other rights of property ownership through a conservation easement. Among those are economic and tax implications of either selling or donating conservation easements. Some tax benefits depend upon whether an easement is donated or sold, and some do not. Tax implications generally fall into one of 5 broad categories: income taxes (federal and state), estate taxes (federal and state) and property taxes. Since Florida has no state income tax, we will not explore their implications here as they vary widely from state to state and cannot be generalized.

In general, a landowner who sells a conservation easement to a qualifying organization will have to report proceeds from the sale as either ordinary or capital gains income for tax purposes. Landowners who choose to donate an easement may receive federal income tax and additional federal estate tax benefits. Tax benefits are only allowed for "qualifying conservation contributions" as defined by the Internal Revenue Code (IRC) Section 170(h).

Donations can also only be made to qualifying conservation organizations. The Internal Revenue Service keeps a list of those organizations. They generally include federal and state natural resource management agencies such as one of the seven Water Management Districts in Florida, and IRC Section 501(c)3 nonprofit, tax exempt land trusts. A more complete list of qualifying organizations for Florida 
residents can be found on the Land Trust Alliance Web site (www.lta.org).

\section{Federal Income Tax Benefits}

In most cases federal income tax deductions in any year can be claimed for up to $30 \%$ of an individual donor's adjusted gross income if the easement qualifies as a charitable contribution and is donated to a qualified conservation organization. Excess value of the conservation easement not claimed may be carried over for an additional 5 years at the same $30 \%$ limit per year. For example, assume the value of a donated conservation easement is $\$ 150,000$ and the grantor's adjusted gross income is $\$ 90,000$. A deduction from adjusted gross income of $\$ 27,000(\$ 90,000 \times .30)$ may be taken in the first year. This leaves $\$ 123,000(\$ 150,000$ - $\$ 27,000)$ of easement value that can be carried over to the next year, and so on. In this case, if the grantor's adjusted gross income stays the same over time, the entire amount can be deducted over the entire 5-year carry-forward period.

\section{Property Tax Benefits}

To obtain property tax reductions in Florida, conservation easements must meet requirements of state law, in particular Florida Statutes, Title XL, s. 704.06. Most property taxes are assessed at the county level, and reductions in a property's fair market value should, in theory, reduce property taxes, independent of whether the easement was donated or sold. However, county property appraisers in general may be reluctant to reduce property taxes as that reduces county revenues. Therefore, if a reduction in the property tax is an important consideration in the decision to obtain an easement, it is a good idea to contact the county appraisers office beforehand to see if a conservation easement will indeed reduce, and by how much, the property tax.

In Florida, if property is already receiving favorable tax treatment via an agricultural assessment (or other "current valuation"), it is unlikely that a conservation easement will further reduce the property tax. If land is not already in an agricultural assessment, it may be classified as such, but there are no guarantees. An agricultural assessment is an agricultural production oriented classification, and easement property may have little or no production characteristics associated with it. Nonetheless, land not already in an agricultural or some other tax favorable classification may benefit from a property tax reduction depending upon the post easement fair market value, the types of encumbrances specified in the conservation easement, future land use options, and other considerations.

\section{Federal Estate Tax Benefits}

Federal estate taxes may be significantly reduced through either selling or donating a conservation easement. Additional tax benefits may accrue if the easement is donated. The most direct benefit results from reductions in fair market value, and thus the value of the gross estate and the ultimate estate tax burden.

Additional tax benefits may result when easements qualify as a charitable contribution. Section 508 of the Taxpayer Relief Act of 1997, as amended by the IRS Reform Act of 1998 and the Economic Growth and Tax Reconciliation Act of 2001 , allows the exclusion of up to $40 \%$ of property value encumbered by a conservation easement from the gross estate value. This is in addition to any reduction in taxable estate value resulting from the easement itself. The gross estate exclusion amount is currently limited to $\$ 500,000$. Also, the $40 \%$ exclusion is the maximum amount and is on a sliding scale.This amount is reduced if the value of the conservation easement is less than $30 \%$ of the unencumbered property value. The $40 \%$ rate is reduced by $2 \%$ for every $1 \%$ the value of the easement is less than $30 \%$ of the unencumbered property value.

\section{Participating Organizations}

What organizations will purchase a conservation easement? The major state agencies involved with conservation easements in Florida are the: Department of Environmental Protection (DEP) and Water Management Districts. These agencies are particularly interested in buying easements, usually in large blocks, in order to protect watersheds. 
The Nature Conservancy is a non-government organization whose mission is to preserve plants, animals and natural communities that represent the diversity of life on Earth by protecting the lands and waters they need to survive. They are involved in conservation easements and other land acquisitions around the country. Typically, conservation easements are donated to nonprofit organizations. However, occasionally these organizations may purchase easements as an effective leveraging tool to protect more land for less money because fee ownership, possession and many other rights remain with the landowner. A listing of some of these conservation organizations can be found on the Land Trust Alliance Web site (www.lta.org).

\section{Concluding Remarks}

Since a conservation easement should be customized to meet specific objectives for you and the conservation entity, the agreement should contain some flexibility to allow for desired future uses. Try to anticipate future uses that you or your heirs may want to allow on the property that are consistent with the conservation objectives for the property. For example, John Landowner currently has no plans to harvest or plant pines on his land, but he or his heirs may want to allow those types of activities in the future and this activity is consistent with the conservation objectives for the property. A conservation easement is forever so it is important to consider all desired future uses before finalizing the agreement.

It is also essential that the landowner carefully review the implications of the easement with legal and financial advisors before the final agreement. Also, bear in mind that your property will be subject to periodic visits by the conservation organization to verify compliance with the agreement.

The following are some important questions to answer before entering a conservation easement agreement:

-What resources do you and the conservation entity want to protect on your property?
-What activities do you and the conservation entity want to prohibit on your land now and in the future?

-What activities do you want continued on your land?

-Are you willing to convey the rights as required in the agreement?

-What other activities, in addition to those taking place currently, might you or your heirs want to do in the future, that are compatible with your and the easement grantee's conservation objectives?

-Will the easement be transferred if the property is sold?

\section{References}

Bick, S. and H. L. Haney, Jr. 2001. The Landowner's Guide to Conservation Easements (Updated Edition). Kendall/Hunt Publishing Co. Dubuque, IA. 181 pp.

Demers, C. (ed.) 2001. Conservation easements.The Florida Forest Steward, vol. 7, no. 4, Forest Stewardship Publication, Florida Cooperative Extension Service, IFAS, University of Florida. Gainesville.

Stockwell, P. 2001. Deed of Conservation Easement. Florida Division of State Lands. 11 p. 